\title{
Tadeusz Jałmużna (1939-2006)
}

W sobotę, 23 września 2006 r., w swojej rodzinnej miejscowości zmarł nagle Profesor Tadeusz Jałmużna. Odszedł na zawsze, w pełni sił twórczych, pozostawiając niespełnione do końca plany i zamierzenia, które od blisko czterdziestu lat realizował na Uniwersytecie Lódzkim. Zostanie zapamiętany jako Człowiek wielkiego serca, zawsze służący pomocą innym. Emanujące od Niego ciepło i dobro, znane i cenione było nie tylko przez społeczność akademicką. Dla pracowników był szefem przyjacielem, delikatnie inspirującym, dbającym po ojcowsku o ich naukowy rozwój, na co dzień przeżywającym ich prywatne radości i smutki.

Profesor Tadeusz Jałmużna urodził się 3 listopada 1939 r. w Kolonii Łaznów (woj. łódzkie). Po ukończeniu, pod koniec lat pięćdziesiątych XX w., liceum pedagogicznego i studium nauczycielskiego

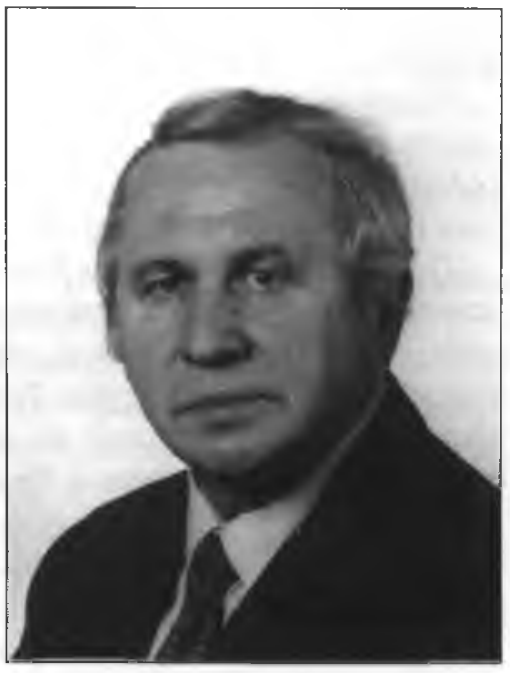
w Piotrkowie Trybunalskim przez rok był nauczycielem języka polskiego w szkole podstawowej w Łodzi. W 1960 r. rozpoczałł studia na Wydziale Filozoficzno-Historycznym Uniwersytetu Łódzkiego, uzyskując w 1965 r., z wynikiem bardzo dobrym, tytuł magistra pedagogiki. Przez kolejne trzy lata zatrudniony był na etacie nauczyciela języka polskiego w liceum ogólnokształcącym dla pracujących oraz pedagoga w poradni wychowawczo-zawodowej w Lodzi. Zainteresowany od początku studiów pracą naukową nie przerwał swoich kontaktów z Uczelnią i zaczął uczęszczać na seminarium doktorskie z zakresu historii wychowania, prowadzone przez prof. S. Truchima i doc. E. Podgórską. $\mathrm{Na}$ cotygodniowych zebraniach szybko dal się poznać jako osoba o ponadprzeciętnej inteligencji, wyjątkowych zdolnościach i pasji badawczej.

W październiku 1968 r. Tadeusz Jałmużna na stałe związał swoje życie i działalność zawodową z Uniwersytetem Łódzkim, zajmując kolejno stanowiska: asystenta (1968-1973), adiunkta (1973-1985), docenta (1985-1990), profesora nadzwyczajnego (1990-2000) i profesora zwyczajnego (2000-2006). Pracę nauczyciela akademickiego rozpoczął w Zakładzie Historii Wychowania i Oświaty, którym kierowała prof. E. Pod- 
górska. Po jej przejściu na emeryturę w 1984 r., objął funkcję kierownika Zakładu Historii i Teorii Wychowania, a od 1991 r. kierownika Katedry Historii Wychowania i Pedeutologii.

Wyrazem zaufania i docenienia Jego kompetencji merytorycznych oraz umiejętności organizacyjnych przez społeczność akademicką był wybór na urząd dziekana Wydziału Nauk o Wychowaniu, który sprawował w latach 1996-1999. Wcześniej współkierował w randze prodziekana Wydziałem Filozoficzno-Historycznym (1987-1991) i Wydziałem Nauk o Wychowaniu (1991-1996).

Przeszło dwadzieścia lat (od 1984 r.) Profesor Tadeusz Jałmużna redagował czasopismo naukowe Uniwersytetu Lódzkiego, początkowo pn. „Folia Paedagogica et Psychologica”, później „Folia Paedagogica”, a następnie „Lódzkie Studia Pedagogiczne”. Dzięki Jego aktywności w tym zakresie szanse publikowania swoich prac naukowych otrzymywali nie tylko pracownicy Wydziału Nauk o Wychowaniu UŁ, lecz także badacze $z$ innych ośrodków akademickich w Polsce.

Niezależnie od działalności redaktorskiej we własnej Uczelni wspierał swoją wiedzą i autorytetem inne wydawnictwa naukowe, będąc członkiem Komisji Wydawniczej przy Łódzkim Towarzystwie Naukowym, Rady Wydawniczej „Przeglądu Edukacyjnego”, Kolegium Redakcyjnego „Życia Szkoły”, Rady Redakcyjnej „Biuletynu Historii Wychowania”.

O trosce i zainteresowaniu Profesora praktyką kształcenia nauczycieli świadczy Jego uczestnictwo w gremiach rozstrzygajacych o kształcie i perspektywach rozwiązań w tej dziedzinie. Nigdy nie odmawiał udziału w zespołach, które wypracowywały koncepcje edukacji przyszłych pedagogów. Takimi motywacjami kierował się przyjmując przewodniczenie w drugiej połowie lat dziewięćdziesiątych XX w. Radzie Programowej ds. Kształcenia i Doskonalenia Nauczycieli przy Wojewodzie Lódzkim oraz od 1991 r. funkcje konsultanta naukowego w Kolegium Nauczycielskim w Zgierzu i Płocku. W przypadku tej ostatniej placówki odegrał istotną rolę w przekształceniu jej w Państwową Wyższą Szkołę Zawodową.

Profesor T. Jałmużna odbywał liczne zagraniczne podróże studyjne do ośrodków uniwersyteckich w Austrii, Niemczech, Czechosłowacji, Litwy i Słowacji. Szczególne miejsce $w$ ostatnich dziesięciu latach zajmowała naukowa kooperacja z Instytutem Pedagogiki w Lublanie (Słowenia). W ramach międzyrządowej umowy zorganizował interdyscyplinarny zespół badawczy, który zajmował się: reformami edukacyjnymi w obydwu państwach, kształceniem i doskonaleniem nauczycieli oraz komparatystycznymi studiami nad terminologią pedagogiczną. Rezultatem tej współpracy były konferencje i wydawnictwa naukowe.

Inny teren zaangażowania Profesora stanowiła działalność w organizacjach naukowych. Był członkiem zwyczajnym Lódzkiego Towarzystwa Naukowego, członkiem założycielem Towarzystwa Historii Edukacji, początkowo członkiem, a później przewodniczącym Komisji Badań nad Pokojem PAN (oddział łódzki).

Prowadzone przez Profesora T. Jałmużnę badania naukowe koncentrowały się na kilku obszarach tematycznych. W latach siedemdziesiątych XX w., przygotowując pod kierunkiem prof. E. Podgórskiej rozprawę doktorską, podjął szerokie poszukiwania źródłowe, których przedmiotem uczynił problem oświaty, nauki i kultury na ziemiach polskich w czasie II wojny światowej. Wyniki wieloletnich kwerend zawarł w szeregu 
rozprawach, wśród których za najważniejszą należy uznać wydaną w 1977 r. książkę pt. Tajne nauczanie na ziemi łódzkiej w latach okupacji hitlerowskiej 1939-1945.

Poważne miejsce w działalności badawczej Profesora zajmowała problematyka nurtów i kierunków w pedagogice $\mathrm{XX}$ w. W publikacjach $\mathrm{z}$ tej dziedziny przede wszystkim podejmował zagadnienia „nowego wychowania” i jego oddziaływania na praktykę pedagogiczną i edukację przyszłych pedagogów: Kierunki aktywności pedagogicznej Jerzego Ostrowskiego (1980), Pedagogika „szkoły pracy" w Polsce międzywojennej i jej wplyw na ksztalcenie i doksztalcanie nauczycieli (1983), Poglady na nauczanie $i$ wychowanie w polskiej pedagogice „szkoly pracy" w okresie II Rzeczypospolitej (1986), Samorzqd wychowawczy Rudolfa Taubenszlaga (1988), Wphyw nowego wychowania na nauczanie języka polskiego (1989).

Niezaprzeczalnym wkładem $w$ rozwój badań pedeutologicznych są rozprawy dotyczące kształcenia, dokształcania i doskonalenia nauczycieli. Ten nurt zainteresowań Profesora zaowocował licznymi wydawnictwami, wśród których przede wszystkim należy wskazać: Nauczyciele życia (1980, współautor), Problemy pedeutologiczne w polskiej teorii pedagogicznej (1987, redaktor), Ksztalcenie i doksztalcanie nauczycieli szkót podstawowych (elementarnych) w Polsce $w$ XVIII-XX wieku (1989, redaktor), Stanisław Marian Dobrowolski, pedagog i oświatowiec 1883-1978 (1992).

Profesor T. Jałmużna należał do grupy historyków wychowania i pedagogów, którzy zainicjowali w Polsce badania nad dziejami oświaty i szkolnictwa regionalnego. Tej problematyce poświęcił szereg zwartych opracowań, przybliżających współczesności rozwiązania z lat międzywojennych i okresu Polski Ludowej. Za szczególnie cenne pozycje dla historiografii oświatowo-pedagogicznej można wymienić: $Z$ dziejów Liceum im. M. Kopernika w Lodzi (1973), Szkolnictwo specjalne w Lodzi do 1939 roku (1993, współautor), Z dziejów akademickiej Łodzi - Wyższa Szkola Pedagogiczna 1946-1956 (1996), Lódzkie czasopisma szkolne w latach międzywojennych (1998), Rola szkolnictwa tódzkiego w tworzeniu dziedzictwa kulturowego Łodzi $w X X$ wieku. Tradycja $i$ wspólczesność lódzkich szkól średnich (2002, redaktor).

Za swoją działalność naukowa dydaktyczna, organizacyjną i społeczną Profesor Tadeusz Jałmużna wielokrotnie był wyróżniany odznaczeniami państwowymi, resortowymi i lokalnymi. Otrzymał między innymi: Srebrny i Złoty Krzyż Zasługi, Krzyż Kawalerski Orderu Odrodzenia Polski, Medal Komisji Edukacji Narodowej, Honorową Odznakę Miasta Łodzi, Honorową Odznakę za Działalność w Województwie Piotrkowskim. 